\title{
The Political \\ Geography of \\ Contemporary Britain
}




\title{
The Political Geography of Contemporary Britain
}

Edited by

\author{
John Mohan \\ Queen Mary College, London
}

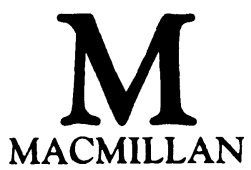


Selection, editorial matter and introduction (C) John Mohan 1989

Individual chapters (in order) (C) Andrew Gamble, Peter J. Taylor, James Anderson, R. J. Johnston and C. J. Pattie, Mark Goodwin and Simon Duncan, Ron Martin, Ray Hudson, Doreen Massey and Joe Painter, Susan J. Smith, Linda McDowell, John Whitelegg, Chris Hamnett, John Mohan, Nicholas R. Fyfe, Philip Lowe and Andrew Flynn 1989

All rights reserved. No reproduction, copy or transmission of this publication may be made without written permission.

No paragraph of this publication may be reproduced, copied or transmitted save with written permission or in accordance with the provisions of the Copyright Act 1956 (as amended), or under the terms of any licence permitting limited copying issued by the Copyright Licensing Agency, 33-4 Alfred Place, London WC1E 7DP.

Any person who does any unauthorised act in relation to this publication may be liable to criminal prosecution and civil claims for damages.

First published 1989

$$
\begin{gathered}
\text { Published by } \\
\text { MACMILLAN EDUCATION LTD }
\end{gathered}
$$

Houndmills, Basingstoke, Hampshire RG21 2XS and London

Companies and representatives throughout the world

Typeset by Latimer Trend \& Company Ltd, Plymouth

British Library Cataloguing in Publication Data The Political geography of contemporary Britain 1. Great Britain. Politics. Geographical aspects I. Mohan, John 320.1'2'0941 


\section{Contents}

List of Figures vii

List of Tables $\quad$ ix

Introduction xi

Acknowledgements xvii

1 Thatcherism and the New Politics 1

ANDREW GAMBLE

2 Britain's Changing Role in the World-Economy 18 PETER J. TAYLOR

3 Nationalisms in a Disunited Kingdom 35 JAMES ANDERSON

4 The Changing Electoral Geography of Great Britain 51

R. J. JOHNSTON AND C. J. PATTIE

5 The Crisis of Local Government: Uneven Development and the Thatcher Administrations MARK GOODWIN AND SIMON DUNCAN

6 Deindustrialisation and State Intervention:

Keynesianism, Thatcherism and the Regions 87 RON MARTIN

7 Rewriting History and Reshaping Geography: the Nationalised Industries and the Political Economy of Thatcherism

RAY HUDSON

8 The Changing Geography of Trade Unions 130 DOREEN MASSEY AND JOE PAINTER

9 The Politics of 'Race' and a New Segregationism 151 SUSAN J. SMITH

10 Women in Thatcher's Britain 172 LINDA McDOWELL

11 Transport Policy: Off the Rails? 187 JOHN WHITELEGG 
12 The Political Geography of Housing in Contemporary Britain

CHRIS HAMNETT

13 Commercialisation and Centralisation: Towards a New Geography of Health Care JOHN MOHAN

14 Policing the Recession 238 NICHOLAS R. FYFE

15 Environmental Politics and Policy in the 1980s 255 PHILIP LOWE AND ANDREW FLYNN

$\begin{array}{ll}\text { Bibliography } & 280\end{array}$

Notes on Contributors $\quad 297$

Index 298 


\section{List of Figures}

6.1 Employment, output and investment in the UK manufacturing sector, 1950-87

8.1 NUTGW - change in percentage share of membership, 1951-82

8.2 Changing geographical base of NUTGW membership, 1951-82

8.3 AEUW membership for England, Wales and Scotland, 1951-82

8.4 NALGO - change in percentage share of membership, 1951-82

10.1 Percentage distribution of women by occupational grouping, Great Britain, 1986

12.1 The regional distribution of new private house building, 1970-85

12.2 Regional house prices as a percentage of London's, 1969-87

12.3 Ratio of house prices to incomes - Nationwide borrowers, 1975-87

14.1 Police forces in England and Wales

14.2 The vicious circle of the collapse of consensus policing 


\section{List of Tables}

2.1 State hegemony and Kondratieff cycles

3.1 Nationalist resurgence in Scotland and Wales: percentage share of the vote in selected UK general elections

3.2 Referenda on devolution, 1979

4.1 Inter-election changes in the percentage of the electorate voting for each party, 1979-87, by geographical region

4.2 Inter-election changes in the percentage of the electorate voting for each party, 1979-87, by functional region

4.3 Vote by perceptions of personal economic situation over the last twelve months and aggregated region

6.1 The decline of industrial employment, 1966-88

6.2 The changing regional impact of deindustrialisation in Britain

7.1 Employment in selected industries, 1978-84 114

8.1 Changes in trade union membership, 1974-85 131

8.2 Membership of the twenty largest TUC unions 1985-7 132

8.3 Employment change and union density by industry 141

9.1 Chronology of political and policy developments relating to racial segregation in Britain

10.1 Employment trends: Great Britain 1971-86 175

10.2 The gender division of labour in manufacturing and the service sector, 1986

11.1 The decline of Britain's railways, 1965-84 190

11.2 British Rail's receipt of government grant aid 191

11.3 Trends in HGV numbers and use 
$\mathrm{x} \quad$ List of Tables

11.4 Car ownership and use in Britain 196

11.5 The development of car ownership in Britain 196

11.6 Local authority areas in Britain at the extremes of car ownership rates 197

$\begin{array}{ll}11.7 \text { Transport expenditures, 1975-84 } & 199\end{array}$ 


\section{Introduction}

For some thirty years from 1945 the economic and social geography of Britain was shaped by a broad consensus comprising, among other things, commitments to full employment, Keynesian techniques of economic management, the welfare state, and a strong regional policy. That consensus has been challenged in the past decade; some challenges have been fundamental, such as the abandonment of any commitment to full employment, while in other policy areas challenges have been partial and less successful (for instance in health care). These changes have had profound effects on the human geography of contemporary Britain and, in order adequately to understand this human geography, an account is necessary of the processes which caused this consensus to break up.

The notion of a consensus is, of course, a difficult one: complete bipartisan agreement between political parties never existed, and differences of emphasis and substance have pervaded all policy areas (as Gamble demonstrates). Nor should the influence of the post1979 Conservative governments be overestimated, since discontinuities in policy were apparent before then, while, for some of the authors in this volume differences between governments of whatever political persuasion have been of minor importance (e.g. Whitelegg, who argues that Conservative and Labour governments have developed policies which have served the needs of the car and the motor vehicle industry above all else, or Hudson, for whom profitability criteria for the nationalised industries are much older than Thatcherism). The authors all attempt to specify both the key discontinuities in policy, to trace the political forces that brought them about, and to separate political changes from secular trends (e.g. Lowe and Flynn, who note that post-1973 awareness of 


\section{xii Introduction}

resource scarcity produced decisive shifts in environmental policy).

Initially, six chapters set the scene by providing contextual material for the analyses of specific policy issues. Gamble considers the extent to which Thatcherism is in fact a new form of politics and whether it has broken decisively with the post-war consensus. Taylor then argues that in order adequately to understand the changing human geography of Britain we need to comprehend Britain's changing position within the capitalist world economy. He traces Britain's declining role as a world power and links this to its changing material circumstances - notably the increased dominance of finance capital. He argues that Britain will be caught between two major geopolitical alliances: the Pacific Rim (the USA, China and Japan) and a European bloc straddling the Iron Curtain and including the Soviet Union. He concludes that, far from seeking to maintain its role as a world power, Britain would be better off more fully integrated into the European bloc.

Britain's changing role in the world economy is important in understanding its present human geography, but equally important are the internal geopolitics of nationalism, uneven development and the spatial distribution of electoral support. In this respect Anderson examines the thesis that the problems of maintaining territorial cohesion could lead to the 'break-up' of the British state. In his view the main impact of peripheral nationalisms will be on the relative strength of the major political parties, not on the cohesion of the state. However, he argues that an increasingly strident British nationalism could disrupt international relations, provoke further nationalist reactions in Scotland, Wales and Northern Ireland and, because of its links with racism, help produce more unrest in the inner cities. Linked to the question of territorial cohesion is the issue of the changing spatial polarisation of the electorate, analysed by Johnston and Pattie. They review the changing electoral map and the various interpretations of the reasons for the changes. They note the lack of a mandate for Conservative rule in the peripheral regions and argue that the Conservatives may develop strategies to 'recolonise' the periphery in order to sustain their legitimacy. One area the Conservatives have sought to 'recolonise' has been the inner city, but they have done so by what Duncan and Goodwin argue is a deliberate and spatially selective attack on the powers and policies of local government. This, they claim, is motivated less by economic considerations than by an attempt to circumscribe the ability of the 
local state to promote alternatives to central policy. In their view, the 'local government crisis' is an attempt to 'still the voices of alternative interpretations and oppositional representation which arise through uneven social and spatial development'.

The problems of managing uneven development and, in particular, deindustrialisation, are then discussed by Martin who constrasts Keynesian and Thatcherite efforts to manage industrial collapse. One basic problem with Keynesian policies was that no coherent policy - in terms of promoting industrial competitiveness, investment and innovation - was ever produced. In reacting against Keynesianism, the Conservatives have revived free-market capitalism in such a way that manufacturing has been pushed into a position where it is possibly beyond revival. Their strategy is not convincing in its assumption that market forces will promote renewal in the old industrial areas, not least because of the counterregional subsidies received by much of South East England in the form of defence expenditures, infrastructural investments and tax reductions. Major developments such as the Channel Tunnel will favour the South East still more, to the detriment of Scotland, Wales, Northern Ireland and the north of England generally (as Whitelegg notes, it is unlikely that the improved cross-London links necessary to spread the benefits of the Tunnel will be built). Martin also notes that the re-emergence of inflationary pressures in the South East may well hinder the Government's anti-inflationary strategy.

The remaining chapters move from these broad considerations to analyses of specific issues. Three key themes run through these chapters: the changing boundary between the private and the public sectors; the changing character of the state and of state intervention; and the emergence of a 'politics of inequality'.

The first of these themes - the changing boundary between the public and the private sector - is central to Hudson's discussion of nationalised industry policy and to Martin's examination of deindustrialisation, where the key issue is the extent to which the market is to play a decisive role in shaping the economic fortunes of different regions and communities. It is also apparent in other chapters, notably Hamnett's discussion of housing policy. The promotion of owner occupation and the sale of council housing have produced an important shift in the tenure composition of the housing stock. These policies are also regarded by Hamnett as 


\section{xiv Introduction}

efforts to 'wean the electorate away from the siren song of socialism' and to weaken political support for collective solutions to housing problems. Indeed some London councils, as Hamnett notes, actually see the promotion of council house sales as a way of weakening the basis of support for Labour within their jurisdiction. Likewise, Whitelegg notes the impact of deregulation on transport policy and observes the effect of running transport systems in a commercial fashion, as in the attempts to make BR reduce its dependency on public funds. Similar points could be made about health care policy where, although the private sector is still numerically small, it has assumed greater ideological significance as there is a growing constituency - heavily spatially concentrated - which can avail itself of private health care. McDowell approaches this issue from a different standpoint for she refers to the changing boundary between the public sphere of work and formal politics, and the private sphere of the family and the home. She argues that current political developments are based on an ideology which seeks to limit women's participation in the public sphere and to confine them to the 'private' sphere by relying on their unpaid labour as sources of care.

Secondly, there is the changing character of the state and the changing nature of state intervention. The attempts to 'roll back' the state are well known and are apparent in chapters dealing with, for example, environmental regulation (Lowe and Flynn), nationalised industries (Hudson), deindustrialisation (Martin), transport (Whitelegg), and housing (Hamnett). Simultaneously, state policy-making has become more centralised with attempts being made to limit local autonomy on several issues. The 'local government crisis' (Duncan and Goodwin) is the most notable example, but this is also true of health care (Mohan) and policing (Fyfe), where numerous examples can be cited of restrictions on the capacity of local agencies to carry through their declared policies. Indeed the view has been advanced that the promotion of the 'free economy' demands a 'strong state' and that this can entail the abolition of local democracy. This is apparent through the setting-up of agencies designed to promote urban redevelopment with minimal local interference (Duncan and Goodwin) or in the proposals to devolve housing management to non-elected organisations (Hamnett). These developments are paralleled by greater coercion, most notably evident in the policing tactics designed to control urban disorders and industrial unrest. Fyfe notes that the notion of a geography of policing is a novel one 
which sits uneasily with the commonly held view of the police as a neutral protector of the common good, but he does show that policing tactics have been carefully orchestrated towards specific places at particular times. Massey and Painter also make the point that the Government's attacks on trade unions have been targeted spatially towards the old industrial heartlands, a view echoed in Hudson's contribution.

Thirdly, a key feature of the last ten years has been the emergence of a systematic politics of inequality. Gamble describes this and reviews the interpretation of Thatcherism as a 'two-nation' politics, in which attempts are made to consolidate and protect support from key social groups and geographical areas (notably the financial and services sector, the professional and managerial groups, and the 'South') while marginalising the unemployed, those working in the public sector and manufacturing, and in the 'North' more generally. One reason for this has been the spatial polarisation of the electorate, which has allowed policies to be pursued which effectively ignore large sections of the country. Two groups most affected by this are ethnic communities and women. Smith traces the emergence of a new 'segregationism', informed by neo-classical economics and a revived British nationalism in the guise of a one-nation Conservatism. This explains the position of black people in housing and labour markets as a function of the operation of market forces, portrays national unity as incompatible with multiculturalism, and dismisses unrest and resistance by black communities as law and order issues, rather than as reactions to structural inequalities and institutionalised discrimination. It therefore denies efforts to remove social and spatial inequalities in black people's life chances. McDowell argues that the position of women has worsened in the 1980 s owing to a combination of the coincidence of wider social and economic changes with the three terms of office of a radical rightwing Government committed to reduced welfare spending. Changes in the labour market, some the result of wider international developments, some resulting from governmental policy, have caused the increased 'feminisation' of poverty. The growing inequalities between those with access to private services and those constrained to depend on the public sector are also clear from the discussions of transport, health care and housing policy.

A further point addressed by some of these contributions relates to the expansion and geography of important social forces and 


\section{xvi Introduction}

political movements. Thus Anderson analyses the actual and potential role of nationalist movements in terms of threatening the coherence of the state. Duncan and Goodwin note how local government has become a force for promoting opposition to central government policies, to the point where central government has deliberately targeted its policies on specific local authorities. Massey and Painter consider the changing geography of trade unions and argue that their decline results from the impact of three factors: economic recession, longer-term changes in economic structure, and the attacks launched by successive Conservative governments on the unions. Lowe and Flynn consider the growth and political significance of environmental movements. These are often specific to particular places, for example the recent emergence of a group of Conservative MPs opposed to the adverse impact of unchecked economic growth in South East England. They note that this could have an important impact on the future direction of Conservative policy, a view apparently confirmed in late 1988 by the rumours of an impending 'greening' of the Government's policies.

Overall, the book forms a comprehensive introduction and sourcebook for those concerned with understanding the changing human geography of Britain. Its chapters cover a wide range of topics in economic and social geography, and it highlights the essentially political factors without which any explanation of this human geography would be incomplete. As such, it is hoped that it will be of value to all those interested in the political dimensions of spatial issues in Britain.

JOHN MOHAN 


\section{Acknowledgements}

The editor and publishers wish to thank the following who have kindly given permission for the use of previously published or copyright material: Basil Blackwell Ltd for the use of a diagram from Losing the Fight Against Crime, edited by R. Kinsey, J. Lea and J. Young (1986); the Nationwide Anglia Building Society for a figure from their publication House Prices: the North-South Divide (1987); the Policy Studies Institute for a table on the development of car ownership in Britain, which first appeared in Plowden, S. (1985) Transport Reform: Changing the Rules; the Longman Group UK for a table, 'State Hegemony and Kondratieff Cycles', from Taylor, P. J. (1985) Political Geography: World-Economy, Nation State and Locality, and for two tables from Johnston, R. J., Pattie, C. J. and Allsopp, J. (1988) A Nation Dividing? The Electoral Map of Britain, 1979-87; the editor of Marxism Today for the artwork for figures from 'Mapping Out the Unions' by D. Massey and N. Miles, Marxism Today, May 1984; and the Controller of Her Majesty's Stationery Office for a figure, 'Percentage Distribution of Women by Occupational Grouping, Great Britain, 1986', from Equal Opportunities Commission (1986) Women and Men in Britain: a Statistical Profile.

The editor is also grateful for the financial support of an ESRC Postdoctoral Research Fellowship (grant no. A23320076) from 1986 to 1989 .

Any edited collection depends on the support of its contributors and the editor greatly appreciates the authors' enthusiasm for the project and for their willingness to respond to his requests for editorial amendments, cuts and so forth. Finally, the editor would like to thank Steven Kennedy of Macmillan for his editorial advice and encouragement. 